\title{
Hawthorne, the Politics of Sin, and Puritanism ${ }^{*}$
}

\section{Tracy B. Strong}

\author{
Give all to love; \\ Obey thy heart; \\ Friends, kindred, days, \\ Estate, good fame, \\ Plans, credit and the Muse,- \\ Nothing refuse. \\ —Emerson, "Give All to Love" (1847)
}

The great nineteenth-century America novels explore American histories as they form Americans; or, more accurately, they attempt to determine the sense(s) that American histories make for Americans-which is not the same thing as writing history. As Hawthorne notes in his 1851 preface to Twice-Told Tales, his intent was to "open an intercourse with the world" (TS 1152). ${ }^{1}$ That history, however, is precisely what he will endow with a "quality of strangeness and remoteness" ( $\mathrm{CH} \mathrm{149})^{2}$ - thus the original historical story will be told a second time, a "twice-told tale."

* I should like to thank Forrest Robinson for a very helpful and critical reading of an earlier draft as well as Robert Wyllie for several suggestions and critiques. The paper has been presented in various instantiations, and I am grateful for comments received, in particular to Matthew Kramer for a question about unpardonable sin. I dedicate this essay to the memory of John H. Schaar, perhaps the last of the Puritan Divines.

1. Citations to the stories are to Nathaniel Hawthorne, Tales and Sketches (New York: The Library of America, 1982), cited parenthetically in the text as TS.

2. Nathaniel Hawthorne, The Scarlet Letter (cited parenthetically in text as SL), in Collected Novels: Fanshawe [F], The Scarlet Letter [including "The Custom-House," CH], The House of the Seven Gables [HSG], The Blithedale Romance [BR], The Marble Faun [MF] (New York: The Library of America, 1983). 
By making actual events strange, he will be able to bring out their true, if usually hidden, nature. This is the project of his first acknowledged novel, The Scarlet Letter (1850), an exploration of the origins of New England and, as he is of New England, of his own inherited identity as an American. ${ }^{3}$

The second and third chapters of Genesis tell us that in the Garden of Eden there were two trees the fruit of which was forbidden: the tree of the knowledge of good and evil and the tree of life. If one were to eat of the former, God warns, one will "surely die" (Genesis 2:17). If one were to eat of the second, one would live forever. Adam and Eve eat only of the former and, in order to prevent them from partaking of the tree of life, God expels them from Eden. Had they eaten of the tree of life, they would have lived with no necessary relation to God as they would have been like God; the indication is that had they remained they would have eaten from that tree. Instead they are expelled into a world where, because they know good and evil, they will die, and in which they know not where they are. The knowledge of morality dislocates us. It is our first sin and the source of our death. It is because we know morality that we are mortal.

If mortality is the price of the first sin, that sin also allows humans to engage in acts for which they can be forgiven. It thus makes necessary human community as only others can forgive me. The second sin, had it been committed, would have made human community impossible and unnecessary. It is because of the first sin that humans live together in a political community. The indication in Genesis is thus that by denying us the second sin, God made human (and thus political) community possible. Where and what is that community?

Emerson opens his great essay "Experience" with a question: "Where do we find ourselves?" ${ }^{4}$ Depending on which word or words you emphasize, you will have five possible different questions. At one point or another, all those questions are Hawthorne's, as they were Emerson's, but, for the topic of this essay, some have priority. For the subject of this essay pride of place goes to the questions of where it is that we are in fact able to find ourselves. If by "finding oneself" is meant finding the self that is truly oneself, then the question is as to what kind of place is a fully human

3. He had previously written Fanshawe but was always reluctant to acknowledge it as good work.

4. Ralph Waldo Emerson, "Experience," in Essays and Lectures (New York: The Library of America, 1983), p. 471. 
place. I take Hawthorne's concerns, therefore, to be, at least among other matters, political in that they seek a common answer to the questions of "who am I" and "who or what are we?" There is no we without a common space - a "where"- and the discovery or recovery or uncovering of the space that one has in common with some others is the basic stuff of politics. A claim is political if in making it for oneself ("I am an American") one also makes a claim on all others who might say that sentence.

These were questions that shaped Hawthorne's life and work. In 1841, he resigned his position as weigher and gauger in the Boston Custom House in order to join the utopian community at Brook Farm in Roxbury. He left after eight months - the experience becomes the basis for The Blithedale Romance - proclaiming, "I can best attain the higher ends of my life by retaining the ordinary relation to society." The first question The Scarlet Letter poses is thus what Hawthorne means by "the ordinary relation."

Upon leaving Brook Farm, Hawthorne rented Emerson's ancestral home, "The Old Manse," and wrote many of his tales in the very office where, as he noted, Emerson had written Nature. He does so, he remarks, as the first lay personage to profane the parsonage, Emerson having been the last of the "great Puritan divines." A second question then has to do with what I will call Hawthorne's layness, his secular Puritanism. Here is a source of the central importance that Hawthorne ascribes to sin.

After three and a half years in The Old Manse, and thanks to his friendship from college with the now President Franklin Pierce, "Providence took [him] by the hand" (TS 1148), and he was appointed surveyor general in Salem. The position was comfortable - too comfortable - and increasingly destructive of the integrity of his person; somewhat to his relief, he is dismissed after the election of the Whig Zachary Taylor in 1848. He found himself, he says, in the position of man who, while contemplating suicide, has the good fortune to be murdered. His experiences at the Custom House serve as the basis for "The Custom-House," the long and famous preface to The Scarlet Letter. Indeed, the plot for that romance is taken, he avers, from a manuscript and a scarlet cloth " $\mathrm{A}$ " he discovered in some old papers while working as surveyor. It is in Salem that he writes The Scarlet Letter, and one must think of this work as an attempt to understand the rigid and dehumanizing world of these new American polities.

5. Letter to David Mack, May 25, 1842, in Selected Letters of Nathaniel Hawthorne, ed. Joel Myerson (Columbus: Ohio State UP, 2002), p. 103. 
Upon finishing the novel he leaves Salem ("this abominable city"), proclaiming that "I am citizen of somewhere else" (CH 157). Of where?

I am thus retained by three interrelated questions from Hawthorne's preliminaries to his novel: What is the "ordinary relation to society"? What is Hawthorne's view of Puritanism? How and of where can one be a citizen? Underlying all of these questions is that of the political and human importance of sin.

To proceed, notice the novel's framing of these issues. The most prominent voice in the book is that of the narrator, a narrator who is introduced as an "autographical impulse" in the Introductory to the novel, "The Custom-House." The narrator has the persona of the Surveyor of Customs, the post he is losing due to the election of Taylor. He refers to his dismissal as a "decapitation." We might then see the narrator as does Marshall van Duesen - and Hawthorne himself — as a "decapitated Surveyor," which may be taken to mean a being who sees without eyes and who appears only to others in words. He spends several pages describing the history of Salem, coming eventually to his own ancestor (who "had all the Puritanic traits, both good and evil" (CH 126)) and his return to Salem (his birth place) after his stay in The Old Manse. Such a return is a "Doom," and he notes that crops planted too often in the same soil do not prosper: "My children... shall strike their roots into unaccustomed earth" $(\mathrm{CH} 128)$. The writer's ramble through Salem and its personages leads him to wonder about the past-for it "was not dead" (CH 142). Some of that past had been taken away by the British during the Revolutionary War, but in a large "unfinished" room there remain "bundles of official documents" (CH 142). He uncovers in a barrel of "rubbish" a document that proves to be the commissioning of Jonathan Pue as Surveyor-to, that is, the very post that he, Hawthorne, has just lost. Included in the packet is much faded "rag of scarlet cloth"- the "capital letter A" (CH 145). The writer gives us the precise dimensions. He places the letter on his breast and experiences an almost "burning heat" (CH 146). (So also will Dimmesdale in the penultimate chapter.) He lets the letter drop, shuddering. As Hester is compelled to wear the letter by the authorities of Boston, in trying on the letter, the author in effect tests their judgment. ${ }^{7}$ The house in

6. Marshall van Duesen, "Narrative Tone in 'The Custom-House' and The Scarlet Letter," Nineteenth-Century Fiction 21, no. 1 (1966): 61-71.

7. There are related thoughts in Nina Baym, "Passion and Authority in The Scarlet Letter," The New England Quarterly 43, no. 2 (1970): 209-30. 
which customs are collected is also the house where Hawthorne will dissect American customs.

The packet also contains several pages handwritten by Pue detailing the story of one Hester Prynne, and the author indicates that he can show this material to anyone who wants to see it. He notes, however, that he will not confine himself to the sheets of foolscap he has recovered, pointing out that those pages are of a private and not official nature. He then imagines being addressed by the ghost of Surveyor Pue and promises in response to write the story of Hester. In obeying Pue (referred to as his "official ancestor," to whom he owes "filial duty and reverence" $(\mathrm{CH} 147)$ ) and writing the story of the scarlet letter, he will in effect give himself an ancestry and past different from that of his actual ancestors - the tale will be told over again. As Nietzsche once remarked, "If one does not have a good father one must give oneself one." 8

Michael Colacurcio has noted that "evidently Hawthorne 'believed in' the power of the past; arguably, he even felt "trapped' by it." A central problem of the novel is thus how to break or transform the hold of the past on the present - while Hawthorne was no Jacobin, the project is revolutionary. ${ }^{10}$ As Hawthorne makes explicitly clear in chapter thirteen of The Scarlet Letter, "the whole system of society is to be torn down, and built up anew" (SL 260). The past of the country must be recreated in order to avoid the problems that have derived from it. I thus resist the conclusion of Judith Shklar that for Hawthorne the solution to constant evil was to be found in private character. ${ }^{11}$ Contrary to the opposition she draws, Hawthorne's project is or will be much more Nietzschean: Nietzsche imagined how tragedy managed to reformulate the Greek Homeric past so as to

8. Friedrich Nietzsche, Human, All Too Human, trans. R. J. Hollingdale (Cambridge: Cambridge UP), p. 150.

9. Michael Colacurcio, The Province of Piety (Durham, NC: Duke UP, 1995), p. 483.

10. Michael T. Gilmore refers to the revolutionary intent of Hawthorne's text in "Hawthorne and Politics (again): Words and Deeds in the 1850's," in Millicent Bell, ed. Hawthorne and the Real: Bicentennial Essays (Columbus: Ohio State UP, 2005), p. 38.

11. Judith N. Shklar, Ordinary Vices (Cambridge, MA: Harvard UP, 1984), p. 40: "Toward others one felt only pity, because thanks to a humiliating religion everyone could identify instantly with suffering and victimhood. Self-made victims, Europeans were now not only a mass of self-mortified Dimmesdales; they were mean-spirited weaklings who squelched every spirit stronger than their own by concentrated social force.... For Nietzsche, Hawthorne's placid resignation was an unthinkable, mediocre sham, and cruelty became for him an obsessive and unmanageable preoccupation." 
avoid the rigidities and constraints that that past was engendering. ${ }^{12}$ The leaving of the Custom-House will enable Hawthorne to break free of the "strong arm of his Uncle," not to be, that is, beholden to the State, to be his own person ( $\mathrm{CH} 152)$.

The authorial voice in "The Custom-House" raises two questions. One is of the relation of historical fact to human truth: what is the status of these documents supposedly found and supposedly preserved? While the facts of his find are "authorized and authenticated by the document of Mr. Surveyor Pue" (an actual person), ${ }^{13}$ and he promises to deposit them in the Essex Historical Society, they have unsurprisingly not turned up (CH 146-47). It is also the case, he notes, that he has allowed himself "nearly or altogether as much license as if the facts had been entirely of [his] own invention" (CH 147). The novel is intended to be truthful (i.e., to bring out the truth) rather than historically accurate about the various political actualities that affect and had affected his home and his country, even though the material that will make that truth clear has at best an ambiguous historical status. He wishes, he says, "to give a faint representation of a mode of life not heretofore described, together with some of the characters that move in it" (CH 122). Pue had recorded the story; he will tell it again.

Second, the writing of The Scarlet Letter will allow Hawthorne to "go forth a man" (CH 153) - that is, in detailing the journey of Hester Prynne, he will also detail the achievement of his own self. It will allow him to be a "citizen of somewhere else" (CH 157). However, his novel will not, as do the novels of some authors, "complete his circle of existence by bringing him into communion with it" ( $\mathrm{CH} 121)$. He will "still keep the inmost Me behind its veil" (CH 121). This is a novel about citizenship and not about the (private) life of the author.

In Democracy in America, de Tocqueville takes pain to detail the importance of America's Puritan origins. ${ }^{14}$ One may say that by his complex invocation of his Puritan ancestry — both positively and negatively - in

12. Robert Milder, Hawthorne's Habitations (New York: Oxford UP, 2013) makes frequent parallels.

13. Pue died in 1760; Hawthorne reports in "The Custom-House" what was listed in an article in the Salem Observer on June 8, 1833 (CH 144). Hawthorne is not the only one without a head, as all that is left of Pue is a wig and some bones. See Margaret B. Moore, The Salem World of Nathaniel Hawthorne (Columbia: Univ. of Missouri Press, 1998), p. 26.

14. See Alexis de Tocqueville, Democracy in America, vol. 1, pt. 1, ch. 2. 
writing this book Hawthorne will take the sins and achievements of his forefathers on his head and in an important sense acknowledge and reformulate them. As the sense of sin was central to the Puritan sense of community, the writing of this book is itself a political act of renewal or creation. ${ }^{15}$ Importantly, Hawthorne will do so by presenting the various elements of society in such a manner that it falls to the reader to take each of them consciously upon him- or herself without trying to resolve them into a single "reality"- something he insists should not and cannot be done. Just one example: In chapter seven, "The Governor's Hall," Hester has been called before Governor Bellingham because a move has been made to take her child away from her. During the course of the interview, not to say trial, Dimmesdale (who is of course the unacknowledged father) will urge successfully that they not do so. The following scene occurs just as proceedings are about to start. There is in the hall a suit of armor, of recent making, "so highly burnished as to glow with white radiance" (SL 207). Pearl, who has accompanied her mother, spends some time looking at the 'polished mirror of the breastplate. 'Mother,' cried she, 'I see you here. Look! Look!' Hester looked... and she saw that, owing to the peculiar effect of this convex mirror, the scarlet letter was represented in exaggerated and gigantic proportions, so as to be greatly the most prominent feature of her appearance. In truth, she seemed absolutely hidden behind it" (SL 208). Pearl, we are now told, takes a "naughty merriment" in the reflection (SL 208). ${ }^{16}$ As readers, we simultaneously observe the scene, first, from the perspective of Pearl, who sees an object of amusement; second, from that of Hester, who sees how she will be seen by the authorities; and, lastly, from that of the governing body (the armor standing in for the about to arrive governor), who see her as an adulteress and sinner. In the same time and by the same words, the importance of the symbol and its multiple significances are made manifest. Sin has many faces.

It is thus important to retain the multiplicities of sin and not try to resolve them. Much commentary on this book, however, generally tries to do so; it falls loosely into three categories. For some Hester sinned, and while her sin is less than that of Dimmesdale (who hides his sin) or Chillingworth (who seeks to destroy), it is still sin. For others, Hester appears as a romantic heroine, lawless to the point of being "Nietzschean"

15. See David Stouck, "The Surveyor of the Custom-House: A Narrator for "The Scarlet Letter,"' The Centennial Review 15, no. 3 (1971): 309-29.

16. I owe the idea to quote this passage to the article by Brodhead cited below. 
(a comparison made by Regis Michaud already in 1928), ${ }^{17}$ and there is no real sin except in the eyes of the oppressive community of Puritans. For still others, Hester manifests a conflict of values that only a change in her life can resolve - a sort of Hegelian Aufhebung imperative.

Indeed, the range of interpretations of this novel and its characters is as extensive as the range of interpretations of any great political theoristPlato, Rousseau, Nietzsche, only for a start. In permitting this range, it is important that it not be understood as a didactic novel (like, say, the 1852 Uncle Tom's Cabin). The "DECAPITATED SURVEYOR" who narrates the novel may occasionally appear to try to give us lessons, but it is Hawthorne's artistry that he can have no lasting success (CH 156). Perhaps, as Joel Porte has written, "Hawthorne's purpose... [was] ... to illustrate the process by which past pain and secret suffering flower into moral truth." 18 What is clear is that Hawthorne does not wish to recreate the moralistic didacticism of his ancestors. But the question remains: what can/should we do with the actuality of $\sin$ ?

Hawthorne is concerned throughout all his writing with the space that makes human relations possible, and nowhere is this more apparent than in The Scarlet Letter. In this novel, it is important that all attempts to escape place fail. As a parallel, take The House of the Seven Gables (1851). As with "The Custom-House," the novel is set originally in Salem, now the home of the Pyncheon family. They are a family like any other family, cursed by the greed for property, magnified in their fate only by the attempt to raise themselves above others. Some of the family stays in the ancestral home, accepting that it is their lot to perish. Others refuse this particular recognition of mortality and seek to flee. Clifford Pyncheon, in particular, escapes, first to crime and punishment, and then again, at the end of the novel. This time he leaves by railroad, that great symbolic divider of American towns, which for one hundred and seventy years now has kept those towns from being whole. The tracks divide a town and always tempt one to leave. ${ }^{19}$

Clifford has boarded a train and purchased a ticket, Hawthorne tells us, for no direction in particular, just to ride for pleasure as far as his money

17. Regis Michaud, The American Novel Today (Boston: Little, Brown, 1928).

18. Joel Porte, The Romance in America (Middletown, CT: Wesleyan UP, 1969), p. 98 .

19. Railroad mileage tripled between 1850 and 1860. At the time of writing of The House of the Seven Gables, there were tracks beyond Kansas City. Transcontinental linkage arrived in 1869. 
will take him. Called to account by a "gimlet-eyed" old gentleman as to this strange mode of pleasure, Clifford claims that his pleasure is superior to the old staid ideas of fireplace and home: "In the name of common sense,' ask[s] the old gentleman... 'what can be better for a man than his own parlor and chimney-corner?"' (HSG 574). Clifford replies that these things have not the merit that many good people attribute to them. "My impression is, that our wonderfully increased, and still increasing, facilities of locomotion are destined to bring us round again to the nomadic state" (HSG 574). And he proceeds with a peroration lauding the railroad's potential to "spiritualize travel" (HSG 575). In an inversion of Calvin, he wants to "annihilate...p pilgrimage" (HSG 575) - a theme that Hawthorne had picked up explicitly in "The Celestial Railroad" (TS 808-24). And Hawthorne shows us that it is to no avail. As the railroad leads away, so the telegraph pursues Clifford, reminding him of, and chaining him to, his past. What good will it do that he find himself in some strange town only to discover that everyone is talking about the dead person whose blood is on his hands? "'You are a strange man, Sir!' [says] the old gentleman bringing his gimlet eye to a point on Clifford, as determined to bore right into him. 'I can't see through you!'” (HSG 580). Clifford's lack of transparency means that he is not of the same world as others. Nonetheless his place of origin, the house in Salem, stays with him despite his attempt to escape it: if one cannot escape, what can one do?

We know that Hawthorne went to great pains to get the physical and historical facts of the place of Boston absolutely correct, apparently sometimes writing with an open copy of Caleb Snow's detailed history of the city on his desk. We also know from various secondary sources that Hawthorne was very widely read in American history. ${ }^{20}$ So the first answer to the first question must be that the characters in this novel (as do in some sense the readers) find themselves in Boston.

What, though, is Boston? As Hawthorne presents it, Boston is a city structured by a tension between two poles. One pole, anticipated in early chapters, is set out in the election-day sermon that Dimmesdale preaches just before he reveals his role in the scarlet "A." He speaks with highest eloquence of the relation between the Deity and the community that has

20. The definitive work establishing this is Michael Colacurcio, The Province of Piety. See also Frederick Newberry, "Tradition and Disinheritance in The Scarlet Letter," ESQ 23, no. 1 (1977): 1-26; and Larry J. Reynolds, "The Scarlet Letter and Revolutions Abroad," American Literature 57, no. 1 (1985): 44-67. 
been established in New England and foretells "a high and glorious destiny for the newly gathered people of the Lord" (SL 332-33). Despite, or perhaps because of, the requirements imposed by the potential for glory of the city they sought to found on a hill - "if wee shall deale falsely with our god in this worke wee have undertaken and soe cause him to withdrawe his present help from us, wee shall be made a story and a by-word through the world: wee shall open the mouthes of enemies to speake evill of the wayes of god and all professours for Gods sake," warned John Winthrop aboard the Arabella - while they believe in their perfectibility, the reality and necessity of human sin also overwhelms these Puritans. ${ }^{21}$ The glorious vision of Dimmesdale's sermon is notably without the anxiety of Winthrop's sermon some eighteen years earlier. John Winthrop is alive during the events of most of the novel: he dies less than two months after the execution of Charles I and just before things come to a climax in the novel. For this book he is what Colacurcio calls a "shadow-presence." 22 And shadows fade.

The centrally important tension that Winthrop evoked is fading and has been replaced by institutions of control. We are thus told in the first chapter that "whatever Utopia of human virtue and happiness" the Puritans might have projected, they felt it necessary - and this is the second pole-immediately on arrival to establish both a cemetery and "the black flower of civilized society," i.e., a prison (SL 158). Death and sin, the two fruits of Eden, are foremost and are to be dealt with by enforcement. In his sketch of "The New Adam and Eve," Hawthorne notes that the couple, as they wander through Boston and Cambridge, find a "Court of Justice," a prison, a scaffold, and a cemetery (the Mount Auburn), all of which are "the very symbol of man's perverted state" (TS 751). Both in this tale and more explicitly in the novel, the prison - a description of which opens the first chapter-emblematizes (as per the fruit of the first tree in Genesis) human original sin; if there were no knowledge of good and evil there would be no prisons. The cemetery, as we shall see, is the counter to the darkest of human traits, what Hawthorne in Ethan Brand calls the "Unpardonable Sin" (TS 1051-67).

The sin, for which Ethan Brand went searching and found, is importantly in or of his own heart. His heart, Brand had found, holds "the sin of

21. John Winthrop, “A Modell of Christian Charity," in Giles Gunn, ed., Early American Writing (New York: Penguin Classics, 1994), p. 112.

22. Colacurcio, The Province of Piety, p. 236. 
an intellect that triumphed over the sense of brotherhood with man, and reverence for God, and sacrificed everything to its own mighty claims!" (TS 1057). Although it is too late, Brand says that if he could live again he would still "incur the guilt" (TS 1057). The sin is the claim that human intellect can and should control the world. It cannot be pardoned because it denies the limitations of our creaturehood: it wants to be like God. ${ }^{23}$ Brand cannot be pardoned because his sin is against himself and not against another. What is important is that an unpardonable sin is unpardonable not because it is a specific act, but rather it is made unpardonable by the sinner him- or herself. It is the fallen equivalent of eating of the second tree.

The committing of unforgiveable sin removes one from a human community or is the attempt to do so. But there are also forgivable sins original to our nature: Hawthorne does not seek to escape from them but to reorient our acceptance of and attitude toward them. The most immediate human articulation of forgivable sins - that is, where they are seen - is the scaffold or pillory on which those deemed deviant from the community are exhibited and punished. The pillory plays multiple roles. It is on the scaffold that Hester is first exposed to the view of the populace after her release from prison. It is on this scaffold that Dimmesdale, in the middle chapter of the book, three times (the reference is Petrine) stonily refuses acknowledgment of who and what he is and has done: the first to the civil power of the Governor, the second time to the demonic power of the witch Mistress Higgins, and finally to the divine power of Reverend Wilson.

23. Blasphemaverit; $\beta \lambda \alpha \sigma \varphi \eta \mu \eta \sigma \eta$. In both the gospel of Mark $(3: 22-30)$ and that of Matthew (12:31), a sin is said to be unpardonable if is a blasphemy against the Holy Spirit. According to the Catechism of the Catholic Church 1864, there are no limits to the mercy of God, but anyone who deliberately refuses to accept his mercy by repenting thus rejects the forgiveness of his sins and the salvation offered by the Holy Spirit. Such hardness of heart can lead to final impenitence and eternal loss. Thus we make our sin unpardonable. Aquinas lists (Summa theologiae II.ii.14.ii-iii), or has responded to, six sins that supposedly go against the Holy Spirit: (1) despair: which consists in thinking that one's own malice is greater than Divine Goodness; (2) presumption: if a man wants to obtain glory without merits or pardon without repentance; (3) resistance to the known truth; (4) envy of a brother's spiritual good, i.e., of the increase of Divine grace in the world; (5) impenitence, i.e., the specific purpose of not repenting a sin; (6) obstinacy, whereby a man, clinging to his sin, becomes immune to the thought that the good searched in it is a very little one. For Calvin, blasphemy is deliberate resistance to the power of divine truth once having been exposed to it (Institutes III.iii.22). See John Calvin, Institutes of the Christian Religion, trans. Ford Lewis Battles, ed. John T. McNeill (Louisville, KY: Westminster John Knox Press, 1960). 
Only the citizens, the polity, are left, and it is to them and from the scaffold that at the end he will finally acknowledge his sin. And, lastly, it is from and on this scaffold that in the penultimate chapter Pearl will for the first time join the human race.

This vision of the perfect society—Winthrop's "City upon a Hill," in which we are commanded to love one another-can no longer be separated from the institutions and structures of sin. Hawthorne's realization, worked out slowly in the Scarlet Letter, is that it was precisely in the free acknowledgment of our own sin that we are able to be free citizens one with the other. Yet not all sins are equivalent. Original Sin - the knowledge of good and evil and the acknowledgment that we most often do the evil while knowing the good (Augustine) - is forgivable and can become the basis for life with others. This ultimate, "Unpardonable Sin"- the selfinflicted desire to control the world and thus to stand outside it as does God - is incompatible with life with others and thus unpardonable. ${ }^{24}$ It is the sin inherent in all unbridled aspirations of science. Dimmesdale commits the first sin; Chillingworth, a doctor and man of science, the second.

It would appear that an unpardonable sin is not so much a particular act as it is a hardening of the heart over time such that one becomes an evil instrument. The sins listed by Saint Thomas in footnote 23 of this essay are qualities of character. They are related to the wish to become like God, or to refuse to acknowledge one's creaturehood, a wish that is unpardonable because were it to succeed, there would be no way to be forgiven - thus God kept Adam and Eve from eating of the second tree. For Hawthorne, one must not act such that one cannot acknowledge that one can be forgiven. ${ }^{25}$ The sin that would come from the eating of the second tree, or from the desire to eat of the second tree, is beyond pardon: "ultimate." Chillingworth has no reverence for another soul and thus cannot be with others, even after death. As Dimmesdale says just before dying, "it was thenceforth vain to hope that we could meet hereafter" (SL 339). ${ }^{26}$ The danger in the Puritanism that had developed in New England was that it would become impossible to tell sin from piety. Hawthorne develops

24. See Sheila Dwight, "Hawthorne and the Unpardonable Sin," Studies in the Novel 2, no. 4 (1970): 449-58. Dwight summarizes other readings of this question very succinctly.

25. See Hannah Arendt, The Human Condition (Chicago: Univ. of Chicago Press, 1998), p. 243.

26. Other committers of unpardonable sin include Ethan Brand (TS 1051-67) and Richard Digby in "The Man of Adamant” (TS 421-28). 
this theme in "The Minister's Black Veil," the story of Parson Hooper who takes to wearing a veil that covers his face down to his mouth and refuses to remove it, even to his fiancée Elizabeth (who leaves him), nor even on his death bed. He is buried with the veil still on. It is no accident that Hawthorne sets this story during the years of the First Great Awakening (TS 371-84). ${ }^{27}$

Boston is a city that none of the main protagonists can leave, even if they try. They do try. In the forest, hoping to flee with her erstwhile lover, Hester questions Dimmesdale: "Doth the universe lie within the compass of yonder town...?" (SL 287-88). To this the minister replies: "I am powerless to go" - that is, to leave Boston (SL 288). Chillingworth himself is irrevocably drawn to Boston (in his case, out of the desire to harm), and when the object of his hatred disappears with Dimmesdale's death, he will also die. One might see the whole novel as a series of misguided attempts to leave Boston, as if a whole life could not be had there, failing to realize that only there could a whole life possibly be lived. (So also, in "The Custom-House," Hawthorne indicates that he is only able to leave Salem, his hometown, by his "decapitation," by, one presumes, in some sense dying to it. $)^{28}$ Hester does leave but voluntarily returns. Only Pearl leaves - it is associated with her saving Dimmesdale - and apparently marries into nobility in England, thereby preserving an all-important tie to the old country.

Where do we find ourselves? First of all in Boston, itself mortally suspended between the pursuit of perfection and sin. The next thing to notice in the story of these citizens, however, is that Boston is surrounded by two worlds. First is England, that is, by its past and that which necessitated its coming to be. A too-young Hester married Chillingworth, explicitly not for or in love, after going from England to Amsterdam; at the beginning of the novel she believes him to be dead; she preserves herself from the gaze of the crowd in the second chapter by recalling her past in England. At the end of the novel she goes back to England with Pearl so that she can start in New England anew and properly as a free person. Even then she maintains the tie by sending ornate pieces of embroidery to Pearl in England.

The timing of the setting in Boston is important. The novel takes place between 1642 and 1649, in other words during the Civil War in England, and so culminates in the year of the execution of Charles I. It is also

27. See the excellent analysis in Colacurcio, The Province of Piety, pp. 314-85.

28. See Robert Milder, Hawthorne's Habitations, pp. 115-17. 
the period, not incidentally, of the transition from the first generation of American Puritans (those who had developed their faith in England) to the second (those who came of age or were born in the New World), a transformation that Hawthorne feels inadequately dealt with and that threatens the integrity and decency of their polity. A central concern of the novel thus has to do with the difficulties in preserving an original vision when a forgetting of the saliency of the past modifies it. Hawthorne will always insist on the importance of the formative quality for American identity and integrity of leaving while not abandoning England. In "Our Old Home," he writes: "we have still an unspeakable yearning towards England. When our forefathers left the old home, they pulled up many of their roots, but trailed along with them others, which were never snapt asunder by the tug of such a lengthening distance, nor have been torn out of the original soil by the violence of subsequent struggles, nor severed by the edge of the sword." 29

The novel takes place at a time when a certain revolutionary free-spiritedness and independence of mind was abroad in the land. The novel ends in the year that Charles I, on a cold day at the end of January, had mounted another scaffold to a public death. Hawthorne recalls the event: "Men of the sword had overthrown nobles and kings. Men bolder than these had overthrown and rearranged - not actually, but within the sphere of theory, which was their most real abode - the whole system of ancient prejudice, wherewith was linked much of ancient principle. Hester Prynne imbibed this spirit. She assumed a freedom of speculation, then common enough on the other side of the Atlantic" (SL 259). We learn that the "world's law was no law for her mind" (SL 259). Hester is thus tempted not to live with others, and indeed she does not for most of the book. She is tempted to overthrow all social order, leading Jonathan Arac in an essay on "The Politics of The Scarlet Letter" to see the novel itself as emblematic of Hawthorne's distrust of revolution and especially of abolitionism. ${ }^{30}$

These were restless times. Zachary Taylor appeared to Hawthorne as a Jacobin. In 1848, two years before Hawthorne wrote his book, there was a Red Scare throughout Europe and a women's rights convention had assembled in Seneca Falls, at which some had declared marriage to be a

29. Nathaniel Hawthorne, Our Old Home: A Series of English Sketches (Boston: James R. Osgood and Co., 1871), p. 23.

30. Jonathan Arac, "The Politics of the Scarlet Letter," in Sarcan Bercovitch, ed., Ideology and Classic American Literature (Cambridge: Cambridge UP, 1986), pp. 247-66. 
form of slavery. The utopian socialist John Humphrey Noyes had called for a "Biblical Communism," urged a "dutiful promiscuity" in communal marriage upon his flock, and proclaimed that his relation to God canceled his obligation to obey traditional moral teachings. All this is known to Hawthorne. Utopian experiments were many, and they often called for cutting off all relation to the past.

Why the importance given to England? The danger for Hawthorne is that in losing their ties to and separating from England, the Puritans would also lose that which had driven them to found a new community overseas. Both the memory and the rejection of England are necessary for the Puritan community (and thus America); both elements are being lost. Just as the community of Israel depends on and is consequent to the exodus from the oppression of Egypt, an exodus recalled each year at Passover, so also does that which it left shape America. Thus the election day sermon that Dimmesdale preaches marks the transition from John Winthrop to John Endicott's second tenure as governor, thus to a new generation and the slow loss of these memories. In his tale "Endicott and the Red Cross," Hawthorne first recreates the scaffold scene, complete with an adulteress wearing a scarlet letter, and then has Endicott (who succeeded Winthrop as governor) rip out the (scarlet) English cross from the flag, a gesture that marks the beginning of the process by which America was to separate itself from England and presumably an attempt to undo its adulterous sin of being joined to England (TS 548). The problem of being America is the problem of dealing with the attraction and guilt of America as an adulterous nation. Hawthorne intends for us, I believe, to have some sense of loss in the removal of the cross: ${ }^{31}$ it is a denial of the importance of the link to England. Endicott, perhaps not so incidentally, will execute several Quakers during his governorship, and his intolerance will be deemed worthy of note in the 1911 Encyclopedia Britannica.

The (a) subject of the novel is then not just a critique of what Hawthorne saw as the gradual development of a tyrannical rigidity, but more importantly of the loss of some of its utopian and rebellious attractiveness and thus of a possibility of an authentic citizenship, a loss that given the recent American election results seems to me to continue to shape my country. What does Hawthorne find happening to his country? A tellingly critical moment comes in his presentation of Pearl. The child is, we are told, not accepted in the games of the children of the settlement. And

31. See Colacurcio, The Province of Piety, pp. 230-35. 
what are these games? They are "scourging Quakers; or taking scalps in a sham-fight with the Indians; or scaring one another with freaks of imitative witchcraft" (SL 198). These are the children that will be the leaders of the next generation, and these games will become their everyday realities: the persecution of the Quakers, genocide against the Indians, and the hunting down of witches. A final game is "playing at going to church," as if the Church to which they will claim allegiance when grown-up had lost or was losing its integrity (SL 198). In "Dr. Bullivant," Hawthorne writes that "the early settlers were able to keep within the narrowest limits of their rigid principles, because they had adopted them in mature life, and from their own deep conviction, and were strengthened in them by that species of enthusiasm which is as sober and as enduring as reason itself. But if their immediate successors followed the same line of conduct, they were confined to it, in a great degree, by habits forced upon them, and by the same severe rule under which they were educated, and in short more by the restraint, than be the free exercise, of the imagination and the understanding" (TS 36). A membership that had been a free choice now had become a compulsion. ${ }^{32}$ And a major loss, as Hawthorne sets it out in the Scarlet Letter chapter on "A New England Holiday," as he had already in "The Maypole of Marymount," is this "dim reflection of a remembered splendor" of "how to be merry" - a now "forgotten art of gayety" (SL 317, 318).

These Puritans - these Americans - continued to believe that they were founding a utopia. Hawthorne identified as a dangerous desperation the Puritan attempt to ensure that by will and repression they would remain true to the vision that had led them to flee from Laud's persecution and their "Old Home." It is the willful pursuit of community that disturbs Hawthorne. It is thus important that it was "Providence" that takes Hawthorne by the hand, for he knew that true community cannot be sought. No one can become a person by trying to be one; no country can become something by force of will without losing its soul - that is Hawthorne's teaching. "We" and "I" cannot be the aim of a project, nor preserved by a congressional committee, and this is what bothers Hawthorne the most about Boston and America. America is or can be exceptional, but only if one does not try to make it so. (Should one try to, the risk is that the

32. Max Weber has similar thoughts in the last pages of The Protestant Ethic and the Spirit of Capitalism. 
country will become what Melville calls in Israel Potter-a book Hawthorne goes out of his way to cite in Our Old Home- - the "[John] Paul Jones of nations." $)^{33}$ This is what was wrong with Brook Farm/Blithedale. Hawthorne's account is a romance about place and friendship, but of a place destroyed by the intentional pursuit of self and community, what he calls "one-eyedness" (i.e., a lack of perspective) in Our Old Home. (Ralph Ellison, incidentally and not so incidentally, will make "one-eyedness" a central theme of Invisible Man.) In The Blithedale Romance, speaking of Hollingsworth, Coverdale says that those who incorporate themselves into "an over-ruling purpose" are finally converted to "little else save that one principle.... They have no heart, no sympathy, no reason, no conscience. They will keep no friend, unless he make himself the mirror of their purpose; they will smite and slay you, and trample your dead corpse underfoot, all the more readily, if you take the first step with them, and cannot take the second" (BR 693). An "ordinary" relation to society cannot be sought and does not respond to intentional will. To try and make it thus is an unpardonable sin. Hawthorne is conservative in the way that, say, Michael Oakeshott is.

Lastly, if the place of the novel is constantly referenced to England, that place is in proximate fact surrounded by the forest, by the wild. The forest is everything that Boston is not. It is from the forest that Chillingworth appears accompanied by "savages." It is the locale of that for which there is no forgiveness, whether out of natural innocence or self-inflicted hardness. It is in fact Chillingworth's place: "Art thou like the Black Man who haunts the forest round about us?" asks Hester of him when they first meet (SL 184). It is to the forest that the witch Hibbins tempts Hester. It is the natural locale for Pearl. It is the locale of sin, as we are given to think that Dimmesdale and Hester's affair took place in the forest, and it is in the forest that they agree to escape together. It is a place in which they think they may be happy but in which, Hawthorne makes clear, they can be neither happy nor at rest. Note that it is only when Pearl kisses her father on the scaffold that she is released from the temptations of a nonhuman ancestry and that she cries her first tears, tears that are, Hawthorne says, "the pledge that she would grow up amid human joy and sorrow, nor for ever do battle with the world, but to be a woman in it" (SL 339). She

33. Herman Melville, Israel Potter: His Fifty Years of Exile (New York: G. P. Putnam, 1855), p. 197. 
fulfills the role of the savior for the community-indeed, she was seen in the second chapter (which we would see if we were what Hawthorne calls Papists) as the Christ child. Without sin, Pearl saves Hester for the community, but importantly, in doing so, she is the only one able to leave it: political community has no place for saviors, for those without sin. If it had not been for Pearl, Hester might have become, Hawthorne tells us, the founder of a religious sect (like Anne Hutchinson, to whom she is made parallel) $)^{34}$ or a prophetess and would most likely have been put to death for attempting to "undermine the foundations of the Puritan establishment" (SL 260). In chapter eight, Pearl is held to have saved Hester from "Satan's snare" (SL 218). Hawthorne's endeavor, however, is not to undermine the foundations but to recover and revitalize them through his art.

Who, though, is the "we" in this Boston? It is for Hawthorne a group of people who have done away with the "system of ancient prejudice," of "nobles and kings" (SL 259). Yet this achievement defines Hester more than they do Bellingham, Wilson, and the others, who think it naturally right that they should protect Pearl by removing her from Hester's care. There is thus a tension in the book between those who want to protect the private (as does Hester by not revealing the name of the father) and those for whom the private-public distinction is close to transparent. ${ }^{35}$ Hester is clearly contrasted with the group of women of "boldness and rotundity of speech" who think her sentence far too light and would that she had been branded (SL 161). By the end of the book, however, Hester has assembled a kind of consciousness-raising group: "people brought all their sorrows and perplexities, and besought her counsel, as one who had herself gone through a mighty trouble. Women, more especially-in the continually recurring trials of wounded, wasted, wronged, misplaced, or erring and sinful passion - or the dreary burden of a heart unyielded, because unvalued and unsought - came to Hester's cottage, demanding why they were so wretched, and what the remedy!" (SL 344). She recalls and reforms the community, the task to which Hawthorne had set himself. I shall not pursue the latent and not so latent feminism of this book further here except

34. It is worth noting however that despite Hawthorne's referring to the "sainted Anne Hutchinson," his early article "Mrs. Hutchinson" (TS 18ff) is overall quite critical.

35. I am influenced here by Michael P. Gilmore, "Hawthorne and the Making of the American Middle Class," in Christoph K. Lehmann, ed., Discovering Difference: Contemporary Essays in American Culture (Bloomington: Indiana UP, 1993), pp. 88-104. 
to note that Hawthorne is clear that the relations between the sexes require a "mightier change" (SL 260). ${ }^{36}$

The forest that surrounds Boston stands for "an unredeemed, unchristianized, lawless region" (SL 292). It is likely the place where Pearl was conceived, and explicitly not a place for Dimmesdale. His health is "so inadequate to sustain the hardships of a forest life... his entire development would secure him a home only in the midst of civilization and refinement" (SL 303). The forest is, on the other hand, a potentially natural place for Hester: "She had wandered, without rule or guidance, in a moral wilderness; as vast, as intricate and shadowy, as the untamed forest" (SL 290). How does she come to deal with this temptation- not to live with others, despite having been exiled?

In chapter thirteen, a little more than halfway through the book, we are told that "the scarlet letter had not done its office" (SL 261). What is (or are) its office(s)? We know that "the scarlet letter was her passport into regions where other women dared not tread" (SL 290). The letter stands for many things. It stands for adultery. As it was also often the case that adulteresses were required to wear an "AD," it can stand for Arthur Dimmesdale. It stands for "Angel," for "Amor," for "Able" (the role in which the citizens come increasingly to see her), and Leslie Fiedler is probably right to suggest it stands for Adam, in "whose sin sinned we all." ${ }^{37}$ As Richard Brodhead notes, the multiple significations of the "A" provide entry into each of the main characters of the book, including the Puritan community. ${ }^{38}$ At some level Pearl herself is the scarlet letter, as we are told that she is the "emblem and product of sin" (SL 198) and "a living hieroglyphic" (SL 297). This means that sin produces one who does not $\sin$ and is the redeemer. Our sin is the source of our salvation.

What then is the office of the letter? In all the above, it recalls human $\sin$. What the letter first does is to separate Hester from the communitywhen imposed by the town on Hester, it cannot do "its office." It is in her embroidering it and wearing it openly and proudly on her chest that she can only then move to become who she is. In the forest, Dimmesdale

36. See Nina Baym, "Thwarted Nature: Nathaniel Hawthorne as Feminist," in Fritz Fleischmann, ed., American Novelists Revisited: Essays in Feminist Criticism (Boston: G. K. Hall, 1982), pp. 58-77.

37. See Leslie Fiedler, Love and Death in the American Novel (New York: Stein and Day, 1960), p. 230.

38. Richard H. Brodhead, Hawthorne, Melville and the Novel (Chicago: Univ. of Chicago Press, 1976), p. 47. 
proclaims: "Happy are you, Hester, that wear the scarlet letter openly upon your bosom! Mine burns in secret" (SL 283). Sin kept secret destroys; sin openly acknowledged liberates. More is needed though: only at the end, when she returns from England and takes up the "A" again, now voluntarily, does she attain what Hawthorne refers to as a "more real life": "Here had been her sin; here, her sorrow; and here was yet to be her penitence. She had returned, therefore, and resumed-of her own free will" (SL 344).

In the end therefore, and I take over and modify a point made by Sarcan Bercovitch, ${ }^{39}$ the "A" is the axial point of the possibility of true community. Much as with the multiple readings of the image in the suit of armor noted above, it is precisely in the multiple and changing readings of the " $\mathrm{A}$ " that the community finds its integration. Hawthorne integrates Hester into the community as an instrument of change, one in which there is promise at least that "at some brighter period, when the world should have grown ripe for it, in Heaven's own time, a new truth would be revealed, in order to establish the whole relation between man and woman on a surer ground of mutual happiness" (SL 344). This means, however, that $\sin$ is the foundation of citizenship and community.

Hawthorne is telling us that we cannot be without sin, and that the claim that we only sin inadvertently, or out of passion, or self-protection, is actually often a way of avoiding the acknowledgment of our sin. Melville referred to "the power of blackness" in Hawthorne and His Mosses, where he spoke of Hawthorne's "sense of Innate Depravity and original Sin, from whose visitation, in some shape or other, no deeply thinking mind is always and wholly free": what we must do is freely to take and acknowledge the sin as our own-precisely what Dimmesdale does at the end. ${ }^{40}$ It is precisely as sinful and imperfect creatures that we must choose our lives - as such creatures. Thus in "The Birthmark," the desire of the husband to remove by means of science (Brand's "intellect") a blemish on his beloved wife, the blemish that marks her creaturehood, leads to her death. Our mortality, itself consequent to our sin, makes life with others possible and central to our humanity —one doubts that Heidegger ever

39. See Sarcan Bercovitch, The Office of the Scarlet Letter (New Brunswick, NJ: Transaction Publishers, 2013).

40. Herman Melville, "Hawthorne and His Mosses," in Harrison Hayford, et al., ed. The Piazza Tales and Other Prose Pieces, 1839-1860 (Evanston and Chicago, IL: Northwestern UP and Newberry Library, 1987), p. 243. 
read Hawthorne, but the thought is cousin. Likewise, Chillingworth's proceeding supposedly to "cure" Dimmesdale medically only serves to make his sin more evident. Knowledge and science cannot be the grounding of political community.

While appreciative of its intensity and its force, Hawthorne thus rejects the ecstasy Hester and Dimmesdale feel in the forest when they agree to go off together. I disagree thoroughly with the reading by Denis Donoghue, when he asserts a propos this passage that "The narratorwe may call this figure Hawthorne - seems to insist that love and nature are insuperable values, that morality has nothing to say to them." ${ }^{, 41}$ The narrator, as I argued above, is the decapitated surveyor: Hawthorne, but not quite. For Hawthorne, it is precisely our imperfections, our sinfulness, that are our redemption and the basis of true communion. When in community one with the other, we are, as it were, our own saviors. Hence Hester's adultery is also a felix culpa, for it is that which enables her to be redeemed from the temptations of inhumanity. But it is also adultery that keeps Dimmesdale from being and thinking himself an angel and thus leaving humanity. It is Dimmesdale who saves, or rather is saved by, Pearl and is forgiven. Not all culpae are felices, however. Chillingworth cannot be redeemed, for he has hardened his heart and sought not to be human but to be God.

Henry James was thus partly right when he wrote (as had Melville) of Hawthorne that "the Puritan strain in his blood ran clear," but it is a Puritanism that is, one might say, secular, or that transcends these categories. ${ }^{42}$ It is a Puritanism with a doctrine of sainthood but without a doctrine of election, one might almost say without God. Calvin wrote that "civil government has as its appointed end, so long as we live among men, to cherish and protect the outward worship of God, to defend sound doctrine of piety and the position of the church, to adjust our life to the society of men, to form our social behavior to civil righteousness, to reconcile us with one another, and to promote general peace and tranquility. All of this I admit to be superfluous, if God's Kingdom, such as it is now among us, wipes out the present life. But if it is God's will that we go as pilgrims upon the earth while we aspire to the true fatherland, and if the pilgrimage requires such helps, those who take these from man deprive him of his

41. Denis Donoghue, "Hawthorne and Sin," Christianity and Literature 52, no. 2 (2003): $215 \mathrm{ff}$.

42. Henry James, Hawthorne (New York: Harper \& Brothers, 1899), p. 10. 
very humanity." ${ }^{43}$ Take God away from Calvin and in this passage you have Hawthorne.

Where do we find ourselves? For Hawthorne we are to find ourselves with each other, without God, and the path to such community is the acknowledgment of our imperfection, the free assumption of our constant and never surmountable sinfulness. This is, or was, the source of our or any common vision. ${ }^{44}$ Such an acknowledgment is the basis for becoming what we are.

43. Calvin, Institutes of the Christian Religion, II.xx.2.

44. I thus differ slightly from my old friend Carey McWilliams. He writes in The Idea of Fraternity in America (Berkeley: Univ. of California Press, 1973), p. 310: "Politics begins with the recognition of the fact of original sin and the destructive consequences of that $\sin$. Yet $\sin$ is only the negative side of the positive vision. Hawthorne knew that a society in which men see in their fellows only a reflection of their own guilt would be full of suspiciousness, resentment, and hostility. Political life demands a 'holy sanction' for its justice, a common vision and a shared purpose. Those who share the goal will be aware that they fall short of it, but knowledge of imperfection is endurable precisely when all have that knowledge. Sin derives from a desire for unconditional affection, a demand to be loved for what one is now, not because of what one strives to be." 